This item was submitted to Loughborough's Research Repository by the author.

Items in Figshare are protected by copyright, with all rights reserved, unless otherwise indicated.

\title{
Towards hypermedia campaigning? Perceptions of new media's importance for campaigning by party strategists in comparative perspective
}

\section{PLEASE CITE THE PUBLISHED VERSION}

http://dx.doi.org/10.1080/1369118X.2014.993679

\section{PUBLISHER}

(C) Taylor \& Francis

\section{VERSION}

AM (Accepted Manuscript)

\section{PUBLISHER STATEMENT}

This work is made available according to the conditions of the Creative Commons Attribution-NonCommercialNoDerivatives 4.0 International (CC BY-NC-ND 4.0) licence. Full details of this licence are available at: https://creativecommons.org/licenses/by-nc-nd/4.0/

\section{LICENCE}

CC BY-NC-ND 4.0

\section{REPOSITORY RECORD}

Lilleker, Darren G., Jens Tenscher, and Vaclav Stetka. 2014. “Towards Hypermedia Campaigning? Perceptions of New Media's Importance for Campaigning by Party Strategists in Comparative Perspective". Loughborough University. https://hdl.handle.net/2134/22387. 
"Towards Hypermedia Campaigning? Perceived Importance of New Media by Party

Strategists across Europe"

Darren G. Lilleker, Jens Tenscher \& Václav Štětka

Dr. Darren G. Lilleker*

Bournemouth University

Media School

Fern Barrow

BU12 5BB, Poole

United Kingdom

Phone: +44 / 1202965622

email: dlilleker@bournemouth.ac.uk

Dr. Jens Tenscher

University of Trier

Faculty III / Political Science

D-54286 Trier

Germany

Phone: +49651/2012137

email: tenscher@uni-trier.de

Dr. Václav Štětka

Charles University in Prague

Institute of Communication Studies and Journalism,

Smetanovo nábřeží 1

11001 Praha 1

Phone: +420222 112166

email: stetka@fsv.cuni.cz

* corresponding author 


\section{Abstract}

This paper analyses strategic thinking around election campaign communication in a rapidly evolving media environment, characterized by the rise of digital communication channels and online social networks as new tools of political campaigning. Using an expert survey to campaign managers of sixty eight political parties within twelve European nations, representing both old and new EU member states, the study investigates the perceived importance of different types of communication platforms in meeting campaign objectives, especially with regards to differences between new and direct modes of campaigning in comparison to traditional campaign channels. The attributed significance to these various channels is then analysed against a range of variables on macro (country) level as well as meso (party) level. The results suggest that while some differences can be observed in regards to the perceptions of particular types of social media between individual strategists working for parties as well as between strategists working in new and old EU member states (e.g. Facebook is seen as more important in younger democracies), overall we can see a relatively high level of homogeneity in the perceived importance of campaign communication in the sample. The data points to the embedding of new communication platforms within election campaign strategies across most nations and parties; this indicates that the move towards "hypermedia" campaign style, integrating both old and new campaign tools and communication platforms, is now becoming a standard feature of professional campaigning strategy in Europe.

\section{Keywords}

New media, campaigning, professionalization, political parties, European Union 


\section{Introduction}

There is a widespread consensus that trends captured by the terms professionalization, marketization and mediatization explain dramatic shifts in the way parties execute their election campaigns (for review see Lilleker, 2014). These broad concepts provide a wideranging assessment of new forms of politics and new types of relations between politicians and voters (Negrine \& Papathanassopoulos, 1996; Mazzoleni \& Schulz, 1999; Blumler \& Kavanagh, 1999), but there are few attempts to understand how campaigns are designed, what the strategic priorities are when developing a communication plan and how these can be explained. This is particularly true when one considers the vast suite of communication options that are available in the digital age. The advent of Web 2.0 (John, 2013) and the subsequent boom in the usage of social network sites (SNS) in particular, has significantly enhanced opportunities for direct communication and interaction between political actors and citizens (Lilleker \& Jackson, 2010) and has challenged the top-down, centralised mode of communication synonymous with the third or postmodern age of political communication (Blumler \& Kavanagh, 1999; Norris, 2003). Web 2.0 has brought fresh challenges for both electoral marketing practitioners as well as for political communication theorists and researchers. In light of the rapid permeation of Internet and social media into the sphere of democratic politics, Jay Blumler has recently announced the possible end of the "third age of political communication" (Blumler \& Kavanagh, 1999), the concept which was an attempt to capture the key features of the way politics is communicated from the 1990s on. According to Blumler, while many characteristics of the previous era are still in place, we might be already witnessing the emergence of a new age, with online communication technologies assuming an ever more important role in the nexus between political actors, voters and journalists, and forcing politicians to significantly broaden their repertoire of communication tools and campaign strategies. As Blumler puts it, 
"If there is a fourth age of political communication, its crux must be the everexpanding diffusion and utilization of Internet facilities - including their continual innovative evolution - throughout society, among all institutions with political goals and with politically relevant concerns and among many individual citizens. /.../ Whereas in the past political leaders and their strategists geared up to cover and intervene in television, radio and press outlets, now they are involved to a considerable extent in multi-dimensional impression management" (Blumler, 2013).

Following the success of the 2008 Barack Obama campaign, which is broadly considered to have been the first to fully exploit the potential of the online environment and utilize social media, there has been a surge in adopting new media and especially social networking sites for electoral mobilization across the Western world (Lilleker \& Jackson, 2010; Johnson \& Perlmutter 2010; Cogburn \& Espinoza-Vasquez, 2011). Despite the widespread turn towards “Web 2.0 campaigning” (Lilleker \& Jackson, 2010; Gibson, 2013), allowing parties to bypass the editorial control of traditional news media organizations (Zittel, 2004) and significantly reduce campaign costs (Gueorguieva, 2008), parties have not abandoned the older tools and campaign techniques. Indeed, some scholars argue that even today, the 24/7 mass media still remain the dominant priority for campaigns, especially as they continue to be the primary source of information for the general population (see Lilleker \& Vedel, 2013). Hence it is argued parties now run hypermedia campaigns (Howard, 2006). New media are treated as an addition to, rather than a substitute for, the traditional and "offline" methods of electoral campaigning.

Our data examines the extent of the adoption of hypermedia campaigning, and in particular how new media competes with old media and what factors explain adoption of digital media campaigning. Rather than analysing the use of digital media by parties through an analysis of their websites, as has become a strong trend in academic research (Lilleker \& Jackson, 2011; Gibson, 2013; Lilleker \& Koc-Michalska, 2013), we reassess some of the trends identified in 
those studies through surveys with party strategists. In asking the designers of the campaigns to weigh different communication tools according to their utility to the campaign we gain the perspective of how important new media are in relation to old media, how different new media tools rate against one another as well as data that can be used to explain why different parties, across different political systems, might place more or less emphasis on digital campaigning.

After exploring the trends in digital campaigning learned from previous studies, and situating digital campaigning within the broader trend of professionalization we outline the measures used and present data that explores in detail the perceptions of digital campaigning and explanations based on macro-level (systemic) and meso-level (party) variables prior to drawing some conclusions on the trajectory for digital campaigning.

\section{Comparative research on online political campaigning}

While academic research on the adoption of new media in electoral campaigning is growing exponentially, there are still many gaps in our understanding of the scope and depth of diffusion and the particular factors enabling, fostering or impeding the use of online technologies in campaigns across Europe and beyond. Most research on these topics remains restricted to nationally-based case studies (e.g. Baxter \& Marcella, 2012; Jungherr, 2012; Larsson \& Moe, 2012; Strandberg, 2013; Gibson, 2013; Williams \& Gulati, 2013; Carlisle \& Patton, 2013; Nielsen \& Vaccari, 2013; Macková, Fialová, \& Štětka, 2013) making comparisons difficult, often due to utilizing incompatible methodologies or measures. Reviewing the state-of-the-art of the field, Lilleker and Vedel claim that " $/ . . /$ there is the need for more comparative research and the extent to which not only organizational factors, resources, incentives and orientation, shape Internet use but also the extent to which the political and social cultures, structures and traditions impact upon campaign strategy" (Lilleker \& Vedel, 2013, p. 28). Existing comparative cross-national studies - as scarce as 
they are - usually tend to focus on just one particular type of communication medium or social networking site (e.g. Twitter - see Enli \& Skogerbø, 2013; Vaccari, Valeriani, Barberá, Bonneau, Jost, Nagler \& Tucker, 2013) and/or their geographical scope and diversity is usually rather limited, mostly to a narrow group of countries. Only a handful of studies have so far attempted to encompass broader, pan-European territory and a wider range of communication technologies (e.g. Vergeer, Hermans \& Cunha, 2013).

The paucity of comparative research means information about not just the mere adoption of new media for electoral campaigns, but also on the explanatory factors related to the adoption of specific tools in the parties' campaign repertoire, and their usage, remains patchy. Variations in usage have been proven to correlate with national contexts, more especially the infrastructure, the institutional arrangements, the legal provisions and the political culture which exist in each country (Ward, Owen, Davis \& Taras, 2008). For instance, uses differ in countries with a proportional election system (which tend to promote a nationwide, party-led debate) than in those with a majority system (which are usually more conducive to more localised and individualised electoral campaigns), hence due to national contextual variations different political uses of the Internet emerge. Recent cross-national studies tend to find a broad homogeneity emerging where most parties in most nations adopt digital technologies, with many attempting to copy the Obama model to some extent (Lilleker \& Jackson, 2011). Yet, differences suggest macro-level factors are reducing in their explanatory power. The debate continues, however, as to whether meso-level variables, in particular physical resources such as finances or staff, or the orientation or ideology of the party or candidate, offer the most explanatory power over innovative digital campaigning. Thus we find in literature two competing hypotheses, that candidates or organizations that have the greatest resources at their disposal, or that are more center left, are most proactive online. Sudulich, in a comparative study of Italy, Spain, the Republic of Ireland and Great Britain found ideology was one factor and that the left performed best in terms of interactivity (Sudulich, 2009). 
Alternatively, Copsey (2003) argued that marginalized voices, and in particular those on the extreme right, find the Internet most appropriate for community building. Copsey's finding was confirmed when the outlier within the 2010 UK parliamentary contest was the far-right British National Party. Their website was the only one to match that of Obama in terms of its interactivity (Lilleker \& Jackson, 2011). In Germany and the UK, however, we find the parties with the largest and most innovative presences are those with the largest parliamentary representation and representing centrist viewpoints. The fact that various studies have been undertaken across a range of countries and time-periods mean the findings are indicative but require testing with a wider sample, at a time when usage of the Internet and social media are more deeply embedded within society. Election campaigns offer a perfect opportunity, they are times when innovations are considered and strategists actively weigh up their options. Within broader patterns of innovation, associated with the professionalization of election campaigning, we position the use of digital campaigning as providing new ways to campaign within an ongoing trend of professionalization.

\section{Election campaign professionalism and the new media}

Instead of the commonly used "phase approach" to the process of campaign professionalization, distinguishing between a pre-modern (party and organization-centred), modern (candidate-centred), and post-modern (message- and marketing-driven) phase (Blumler \& Kavanagh, 1999; Norris, 2000, pp. 137-147; Plasser \& Plasser, 2003, pp. 22-24), we see professional campaign management primarily in the ability of parties to mix strategic and structural components of different "phases", and define election campaign professionalism as the degree of a party's adaptations to modernization-related transformations in the campaign environment, which contains a number of structural and strategic components (e.g. Tenscher, Mykkänen \& Moring, 2012). 
Obviously, such an approach to the professionalism of electoral campaigns asks for an investigation of the meso level, i.e. the political parties involved. In recent times, there have been a handful of studies that have taken this route (Strömbäck, 2009; Gibson \& Römmele, 2009; Tenscher et al., 2012; Tenscher, 2013; Tenscher \& Mykkänen, 2014). While Gibson and Römmele as well as Strömbäck have focused on parties' campaign structures (“CAMPROF-index”), Tenscher and colleagues have also investigated parties' campaign strategies. Having turned to campaign managers' evaluations as indicators for the degree of election campaign professionalism, they have analysed the relevance of different communication channels as an integral part of professional campaigning.

Despite these promising attempts, however, we still have little knowledge about the extent to which theoretically derived components of professional election campaigning - including a variety of "new" and direct modes of communication - correspond to the practitioners" perceptions of election campaign professionalism, particularly in a comparative perspective. We want to answer this question by differentiating between "new" and direct campaign channels and their perceived importance for election campaigning.

We therefore test whether components that are regarded as integral to a professionalised strategy are given equal weightings in importance across parties and nations so assessing whether the current "post-modern" phase of election campaigning is characterised by greater granularity than models and theories suggest. Taking granularity rather than homogeneity as an overarching hypothesis we therefore expect both country-and party-dependent differences to explain the importance of "new" and direct modes of campaigning. On the one hand, it has been demonstrated that there are country- and even region-specific patterns of election campaigning in general (Swanson \& Mancini, 1996; Plasser, Scheucher \& Senft, 1999; Norris, 2000; Farrell, 2002; Plasser \& Plasser 2003; Tenscher et al., 2012) and web campaigning in particular (e.g. Kluver, Jankowski, Foot, \& Schneider, 2007; Ward et al., 2008; Lilleker, Koc-Michalska, Schweitzer, Jacunski, Jackson \& Vedel, 2011; Lilleker \& 
Jackson, 2011). We assume that these patterns should result in (or emerge from) diverse understandings of professional election campaigning via "new" and direct communication channels. We especially assume that:

H1: The younger a democracy is, the higher "new" and direct modes of campaigning are perceived as an integral part of professional election campaigning. This hypothesis is based on the assumption that the choice of campaign channels is highly dependent on experience. Since there is a longer tradition with traditional and mediated modes of campaigning in established democracies, the introduction of new modes might be impeded. But:

H2: The perceived importance of new and direct modes of campaigning will be dependent upon their utility for reaching a wide cross-section of a national electorate, so will depend on the national internet penetration figures

On the other hand, variations in strategists" evaluations of the importance of "new" modes of campaign professionalism might be explained by meso factors, namely party's size, ideology, resources and due to facing an internal or external shock (Gibson \& Römmele, 2009;

Strömbäck, 2009; Tenscher et al., 2012; Tenscher, 2013; Tenscher \& Mykkänen, 2014). Against this backdrop, we investigate the following hypotheses:

H3: Strategists working within centrist and catch-all parties will most likely rank all modes of communication as integral to their election campaign strategy given their objectives in reaching the greatest number of voters across a range of social groups.

H4: Strategists working within newer parties will prioritise "new" and direct modes of campaigning, while their counterparts in more established parties will prioritise traditional modes of campaigning.

H5: Strategists working within client parties located at the fringes of the political left-right spectrum will perceive "new" and direct modes of campaigning as more important than centrist, catch-all parties. This assumption is based on the idea that fringe and 
client parties tend to be marginalised within an indifferent mass media environment which makes it more necessary to directly communicate with target groups and voters.

H6: Strategists working within oppositional parties will give higher priority to "new" and direct campaign channels than their counterparts working within governmental parties. Once again, this would reflect the necessity for oppositional parties to compensate their publicity deficit in the mass media as well as having greater freedom to interact with their supporters.

In addition to these general differences, we expect variations between different modes of "new" and direct communication channels which have not been discussed in political communication research so far.

\section{Methodology}

\section{Case selection}

To acquire knowledge of strategists" understanding of the importance of "new" and direct means of campaign communication we conducted a survey among top-ranked party secretaries and campaign managers in twelve European countries all of whom have a key role in strategic planning and design. The countries selected reflect the broad spectrum of political, media-, and campaign-related differences in contemporary Europe (see Table 1).

\section{-Table 1 here-}

First of all, the selected countries vary politically. Most of the selected countries are parliamentary democracies of which three have a monarchical tradition (Netherlands, Spain, and United Kingdom). But the countries vary in democratic experience. While there have been parliamentary elections in France and the United Kingdom since the $19^{\text {th }}$ century, in the new EU member states, Czech Republic, Hungary, and Slovakia, democracy was introduced 
no earlier than 1990. The countries also differ in their electoral systems: Most of the countries examined operate a proportional representation electoral system in which either parties and/or candidates are elected. However, France and the United Kingdom use first past the post, and so candidates and not parties run for election.

Almost all countries have a coalition government, Malta being the exception. In addition, the party systems differ in the number of parties represented in parliament, from two (Malta) to 16 (Spain). In most of the countries, five to ten parties are in parliament.

Second, the countries selected vary in their media environment, representing different "models of media and politics" (Hallin \& Mancini, 2004). Four belong to the Mediterranean, polarized pluralist model (France, Malta, Portugal, and Spain) and four to the North/Central European, democratic corporatist model (Austria, Finland, Germany, and Netherlands). Three countries were classified as "transitory", since their media systems are still under construction, respectively the Czech Republic, Hungary and Slovakia. Finally, the North Atlantic or liberal model is represented by the United Kingdom.

Finally, we selected the countries on their campaign regulations. We have chosen two discriminating indicators: limitations to electoral expenses and restrictions on advertising. While in eight countries electoral expenses are regulated by law, (almost) no limitations exist in the Czech Republic, Germany, the Netherlands, and Slovakia. The Netherlands is the only country in our sample in which electoral campaign advertising is unrestricted. In most other countries moderate regulations of the content, timing, and/or extent of specific (not all) advertisements (e.g., TV commercials, billboards, posters, and trinkets) exist. In France, all paid media activities are strictly controlled.

We selected all parties represented in the European parliament and those parties that were, according to pre-election polls, expected to win at least one seat in 2014. In total, 82 parties were approached. The key individual with oversight of strategic decision making during election campaigns was surveyed, depending on the nation and party these were party 
secretaries, campaign managers or their equivalent (one person per party). ${ }^{1}$ Response rates varied from one party (Malta) to eight parties (France, Netherlands (Table 1). On average, 82.7 percent of those parties contacted participated $(\mathrm{SD}=14.6)$. Our final sample consists of 68 parties. The interviews were conducted between February and September 2013 either faceto-face, by telephone or mail using a semi-standardized questionnaire, which asked respondents to rate the importance to the party of different aspects of professional campaigning in national parliamentary elections. The measures relevant to this paper are detailed below.

\section{Operationalization and method of analysis}

To measure the importance assigned to different modes of professional campaigning, we made use of a set of closed questions. Respondents were asked to state how important each indicator is for a professional national parliamentary election campaign in their country. They could answer on a scale from 1 ("not at all important") to 5 ("very important"). ${ }^{2} \mathrm{We}$ differentiate between indicators measuring traditional and mediated communication on the one hand and "new" and direct campaign channels on the other:

- Traditional and mediated communication: 1) use of paid media such as TV spots, posters or advertisements, 2) presence of party and top candidates on TV.

- "New" and direct communication: communication with voters via 1) email, 2) Facebook, 3) twitter, 4) YouTube, and 5) other new media.

At the macro level we have eleven independent variables which are prominent in the literature to affect modes of campaigning (e.g. Swanson \& Mancini, 1996; Hallin \& Mancini, 2004; Esser \& Strömbäck, 2012):

- Old versus new EU member state (EU-entry before/after 2004),

- Experience with democratic elections (years since the first democratic election took place), 
- Degree of fragmentation of the parliamentary system (the degree of competition in the “political market", measured as number of parties represented in the national parliament),

- Turnout in the last parliamentary elections (measured in percent),

- Size of the population,

- $G D P$,

- Literacy rate (in percent; Source: PISA 2009),

- Internet penetration (in percent; Source: internetworldstats.com, December 2011)

- Interest in politics (four-point-scale, recoded to "strong or medium" and "low" and "not at all”, Source: Eurobarometer 78.1, November 2012),

- Model of media and politics (liberal, democratic corporatist, polarized pluralist, and transitory),

- Campaign regulations (i.e. limitations on electoral expenses and restrictions on advertising).

We have the following independent variables at the meso level:

- Party's age (years since party's foundation),

- Size (percentages of votes obtained at the last national parliamentary election),

- Party type (dichotomous variable differentiating catch-all and client parties depending on the share of votes),

- Parliamentary role (differentiating between governmental, oppositional and extraparliamentary party).

- Ideology (a five-point scale ranging from 1 "far left" to 5 "far right"),

- Internal shock (number of years since the last change in party leadership),

- External shock (difference between percentages of votes gained in last national parliamentary elections and next to last national parliamentary elections). 


\section{Empirical results}

Prior to analysing our data in order to test the hypotheses we explore the data to gain a general sense of media priorities. Table 2 shows that prioritization of traditional modes of communication prevails, but new modes of campaigning are deemed of high importance. The perceived most important mode of communication in the mediated category is television (traditional mode) and this is matched in mean importance by face-to-face communication (traditional mode). Facebook is placed third (new mode) followed by broad canvassing activities (traditional) then communication via email, YouTube, Twitter and other social media platforms. Paid advertising it would appear has the lowest perceived importance. However the standard deviations show much diversity of opinion for most features, it is only television and face-to-face canvassing that is agreed by most respondents to be most important. Therefore, we explore whether our hypotheses have the explanatory power over these divergences in opinions.

-Table 2 here-

\section{Macro-Level factors explaining difference}

Overall macro-level factors show few coherent patterns in differences for media prioritization. Figure 1 shows that there is a clearly identifiable group of nations where party strategists appear to prioritize all forms of communication, whether via mediated and traditional or direct and "new" new modes; they are Austria, Czech Republic, Germany, Hungary, the Netherlands and Slovakia. The diversity in these nations' experiences of democracy, media systems, GDP, literacy rates, internet penetration and political interest offer a clear sense of a lack of any pattern forming that can be explained by macro-level factors. Similarly the three nations where we find strategists prioritize direct and new modes of communication over traditional and mediated are Finland, France and Portugal, again highly divergent systems. 
However these represent broad national averages of disparate evaluations of importance offered by strategists working within very different party contexts that conflate a number of forms of communication into groupings.

-Figure 1here-

Looking at the results of bivariate correlations (Table 3) we find Hypothesis 1 is proven only for Facebook, perhaps indicative of the fact that as Facebook has become the almost global social network of choice, and in young democracies where party systems are more fragile and fragmented, and media do not fully fulfil their democratic role, party strategists see value in occupying spaces within online platforms which offer opportunities to reach the largest number of hard to reach voters. Hypothesis 2 is surprisingly unproven suggesting that all party strategists, independent of the number of people with access to the Internet, see a value in reaching out to the percentage of the electorate that are actually online. One possible explanation for this fact could be that above a certain level, Internet penetration might stop being a factor in the perceived importance of new media in campaigning (the average penetration for the countries in the sample is $79 \%$ ).

-Table 3 here-

That Facebook correlates significantly with the experience with democratic tradition (the younger a nation is, the higher the evaluation), the size of the population (the smaller a population the higher the evaluation) and GDP (the lower the GDP the higher Facebook's evaluation) indicates Facebook is perceived as a catch-all medium. In contrast Twitter correlates positively with GDP only, the higher the GDP the higher Twitter is evaluated. We may suggest Twitter is deemed more effective for reaching a more educated, higher skilled 
population. YouTube correlates negatively with the literacy rate, reflecting perhaps that video is perceived as more important for strategists working in nations with a larger number of lower educated voters. The perceived importance of other new media correlates positively with the size of the population, reflecting that some nations have alternatives to Facebook that remain popular and so with a large population it is worth targeting every group via every available social media. We therefore note platforms may be evaluated based on their perceived appropriateness for campaign contexts.

While statistical analysis offers some indications, due to the small sample it is appropriate to focus on mean scores and standard deviation to explore the data, this is shown in Table 4. It shows that evaluations of Facebook's perceived importance is significantly higher in new EU member states and is highest in transitory states. On the other hand: Twitter is perceived significantly more important in older EU member states. There is some minor impact of the restrictions on advertising on the perceived importance of YouTube and other new media. This may reflect the perceived need to deliver messages directly to voters using every available channel where advertising is heavily restricted. Interestingly evaluations are not affected by limitations of campaign expenses; this may reflect the fact that, independent of restrictions, social media remain a low cost means of disseminating campaign messages.

\section{-Table 4 here-}

\section{Meso-Level factors explaining difference}

Examining the meso-level factors we first compare evaluations of new and direct means of communication versus traditional media. Figure 2 provides a strong sense of the spread of difference between German Greens (Grüne) campaign manager who prioritised all forms of communication (and are a fringe, opposition party) and the UK Independence Party (UKIP) strategist, working for an extra-parliamentary fringe party who had fairly narrow and targeted communication priorities. 
Exploring meso-level differences in more detail we firstly develop usage typologies using a two-step cluster analysis (Table 5). This shows that we are able to construct almost discrete groups of party strategists with differing overall communication strategies. The "Generalists" prioritise all forms of communication, and while we would expect these to be largely centrist and catch-all parties we see from the list some divergence from this pattern with the inclusion of the Hungarian far-right Jobbik party, and German left Linke. "Average users" rate all forms of communication, but to lesser degrees, suggesting they see each as important but perhaps have a more measured view of social media emerging from a less catch-all strategy, again there is a range of divergent party types represented within this grouping. "Selective users" pick from a suite of specific communication tools, these tend to be smaller parties such as UK's junior coalition party Liberal Democrats and the Dutch ChristenUnie. Finally, "Email avoiders" are a group who perhaps prefer using channels that permit broadcasting to all as opposed to collecting emails, building a database and then segmenting and targeting voters. Email avoidance may result from strategists maximizing their low resources, and indeed most work within smaller, fringe parties.

-Table 5 here-

Looking in more detail at meso-level factors, using mean scores and standard deviation as an indication of priorities and the diversity of perceptions, we find (Table 6) one or two interesting patterns. Firstly, as indicated in the cluster analysis, strategists' evaluations of the importance of emails depend on the type of party they work within (catch-all parties assess a higher importance) and their party's position at the left-right-spectrum (centre party strategists 
assess a higher importance to email than their fringe party counterparts). We suggest this is actually a factor of resources, as centrist party strategists tend to have greater resources at their disposal and so can be more ambitious in planning their campaign, although there are no significant differences linked to whether parties are in government, opposition or outside parliament. Strategists' evaluations of Twitter and Facebook are independent from most party-related factors, it would appear usage of these platforms is explained better by macrolevel factors. Oppositional party strategists perceive YouTube as having slightly higher importance, but the real difference is between parliamentary and non-parliamentary party strategist' evaluations of the platform. The reason for non-parliamentary party strategists to suggest YouTube is of lesser importance is most likely to lacking the necessary resources to construct videos hence they may not have considered or explored the platform's potential. The assessment of other new media depend on party type and, particularly, the party position on the left-right spectrum, which may indicate that non-centrist fringe party strategists try to use every available platform in order to make up for any resource differentials they face.

\section{-Table 6 here-}

Multivariate regression operationalizing all meso-level variables (Table 7) shows that, firstly, party's age is the strongest predictor for evaluations of the importance of email, Facebook and YouTube: the younger a party is, the higher these channels are evaluated. This may reflect the strategists seeking for a new party using every available medium. The importance of email is explained by the most variables: party strategists in younger democracies evaluate email higher; similarly the higher the GDP; and the lower people's political interest. Catch-all party strategists evaluate email higher than their client party counteparts; and the longer since a change in party leadership, the higher email is evaluated. This may actually reflect the fact that where resources allow, having a database of contacts is important and email remains a 
"killer app" in acting as a pull medium building awareness and increasing hits on websites, videos or other platforms (Lilleker \& Jackson, 2011). The importance of other new media is higher where strategists face a larger population and limits on campaign expenditure as noted earlier.

-Table 7 here-

Hypothesis 3 is therefore proven for email only, as it is hard to find a clear indication that centrist, catch-all party strategists campaign differently to those working within their more ideologically-driven counterparts. We do find hypothesis 4 proven for email, Facebook and YouTube suggesting that strategists working within newer parties perceive social media as more important. This finding also links well to the macro-level findings where strategists from younger democracies with more fragmented party systems also reported a higher evaluation of social media as a campaign tool. Hypothesis 5 may be proven for other new media platforms only, but in reality we do not find strategists working within client parties on the fringes prioritizing social media, suggesting normalization in uptake across parties and nations. Equally we find little evidence to indicate that opposition party strategists have differing priorities than when working for a party of government, disproving Hypothesis 6. Overall, we find a rather complex picture of the selected meso-level factors having a different kind of impact on the perceived importance of different types of new media, pointing towards the need for a more nuanced understanding be taken towards the prioritization of new communication platforms in campaign strategy in future research.

\section{Conclusion}

In order to determine and explain the embeddedness of hypermedia campaigning through analysis of the evaluations of strategists of differing media platforms we find mixed patterns. 
Macro-level explanations are few. H1 seems to explain perceptions of Facebook's importance only, $\mathrm{H} 2$ is not proven at all. Party strategists in younger democracies seem to see Facebook as more important (possibly due to higher personalisation in weak party systems and the lack of tradition within parties permits greater innovation)

Meso-level indicators are equally mixed. We find clusters of behaviour but no overall patterns, though a hint that there may be a divide with some party strategists placing more weight on traditional modes of communication while others see new media having greater potential to meet campaign objectives. If there is a clear finding it is that most of our respondents, representing the majority of parties across the sample of EU member states, state that new modes of communication are of equal importance to many traditional means of communication and more important than some.

Therefore we suggest our data shows the full embedding of new media by strategists across most nations and parties, and the prioritization of most platforms as opposed to there being patterns defined by national contexts. There are some variances which make logical sense, for example that YouTube is perceived as the best for reaching populations with lower literacy rates and in newer democracies reflecting that video is more suitable for a less educated and politically literate electorate. Largely though we find Facebook is now seen as virtually a catch-all medium. Facebook is definitely a feature of campaigning across all democracies but we see a hint that it is marginally more important among strategists working in transformatory systems. This may suggest that Facebook is seen as more important for building awareness and possibly making connections where a party system is fragile and fragmented. So strategists perceive this as a further platform to use to target hard to reach voters in nations where there is lower partisan loyalty, a fragmented party system and, we would suggest, a more commercial, less public-service oriented media system.

Meso-level explanations to an extent reinforce these findings. The fact that centrist party strategists prioritize the importance of using email and Facebook suggests again these tools 
are perceived as catch-all mediums. Equally reinforcing the notion of these as awareness building tools, and perhaps also relationship building tools, strategists working within newer parties also seem more likely evaluate social media, in particular Facebook and YouTube, highly.

However these minor differences suggest nothing more than a granularity of strategy at the individual level. Stratetgists evaluate highly the communication tools they find to be appropriate within the context in which they operate and hence the weightings they award these tools are shaped by a range of factors. While some of these may be detectable through statistical analysis they may also be due to the personal preferences and prejudices of the individuals themselves Hence the few significant indicators offer hints at explanatory factors but may not tell the full story. Therefore our data overall, and in particular the data extracted on media priorities, suggests homogeneity of thinking across EU political parties. While differences emerge, these may not be as stark in reality. Strategists may use the full suite of communication tools available, though their effort may differ, along with their evaluations; hence seeking homogeneity may be the best explanatory factor for the current fourth, hypermedia phase of evolution in election campaigning.

Yet of course this is based on self-reported priorities and so the ratings may be subject to some degree of interpretation by our sample of respondents. One individual's three may mean highly important whereas another may think, as most, this is average. Furthermore, the responses may reflect aspiration as opposed to what is possible for the party but actual practice may be constrained by resources. Conversely, lower prioritization may not entirely reflect lower effort when we compare responses to actual behavior. Hence while we argue that our data offers a clear indication of standardization of media usage, we equally note that reality may be somewhat different. Yet, we expect the evaluations to reflect effort and resources expended, on that basis we suggest that social media communication is now a serious rival for traditional news management activities and, due to this, one might find 
campaigns evolve further towards using interactive communication, be more co-produced and certainly be more social.

\section{Notes}

${ }^{1}$ We want to thank María José Canel (Complutense University of Madrid), Rui Dias Oliveira (University of Aveiro), Andrej Findor and Olga Gyarfasova (Comenius University), Carlos Jalali (University of Lisbon) Karolina Koc-Michalska (CEVIPOF, Sciences-Po Paris), Tom Moring and Juri Mykkänen (University of Helsinki), Jolán Róka (Budapest School of Communication), Carmen Sammut (University of Malta), Philip van Praag (University of Amsterdam) and Annemarie S. Walter (Free University of Amsterdam) for their participation and permission to use their countries' data.

${ }^{2}$ Missing values were set to 0 . 


\section{References}

Baxter, G., \& Marcella, R. (2012). Does Scotland "Like” This? Social Media Use by Political Parties and Candidates in Scotland during the 2010 UK General Election Campaign. Libri, 62, doi: 10.1515/libri-2012-0008

Blumler, J. G. (2013, September). The Fourth Age of Political Communication. Keynote address delivered at a Workshop on Political Communication Online, the Free University of Berlin. Retrieved from http://www.fgpk.de/en/2013/gastbeitrag-von-jay-g-blumler-thefourth-age-of-political-communication-2/

Blumler, J. G., \& Kavanagh, D. (1999). The Third Age of Political Communication: Influences and Features. Political Communication, 16, 209-230. doi: $10.1080 / 105846099198596$

Carlisle, J. E., \& Patton, R. C. (2013). Is Social Media Changing How We Understand Political Engagement? An Analysis of Facebook and the 2008 Presidential Election. Political Research Quarterly. doi:10.1177/1065912913482758

Cogburn, D. L., \& Espinoza-Vasquez, F. K. (2011). From Networked Nominee to Networked Nation: Examining the Impact of Web 2.0 and Social Media on Political Participation and Civic Engagement in the 2008 Obama Campaign. Journal of Political Marketing, 10, 189-213. doi 10.1080/15377857.2011.540224

Copsey, N. (2003). Extremism on the Net: The Extreme Right and the Value of the Internet. In R. Gibson, P. Nixon \& S. Ward (Eds.), Political Parties and the Internet: Net Gain? (pp. 218-231). London: Routledge.

Enli, G. S., \& Skogerbø, E. (2013). Personalized Campaigns in Party-Centred Politics. Information, Communication \& Society, 16, 757-774. doi:

10.1080/1369118X.2013.782330 
Esser, F., \& Strömbäck, J. (2012). Comparing Election Campaign Communication. In F.

Esser \& T. Hanitzsch (Eds.), The Handbook of Comparative Communication Research (pp. 289-307). New York: Routledge.

Farrell, D. M. (2002). Campaign Modernization and West European Party. In K. R. Luther \& F. Müller-Rommel (Eds.), Political Parties in the New Europe: Political and Analytical Challenges (pp. 63-83). London: Routledge.

Gibson, R. K. (2013). Party Change, Social Media and the Rise of "Citizen-initiated" Campaigning. Party Politics. doi:10.1177/1354068812472575

Gibson, R., \& Römmele, A. (2009). Measuring the Professionalization of Political Campaigning. Party Politics, 15, 321-339. doi: 10.1177/1354068809102245 Gueorguieva, V. (2008). Voters, MySpace, and YouTube: The Impact of Alternative Communication Channels on the 2006 Election Cycle and Beyond. Social Science Computer Review, 26, 288-300. doi: 10.1177/0894439307305636

Hallin, D. C., \& Mancini, P. (2004). Comparing Media Systems: Three Models of Media and Politics. Cambridge: Cambridge University Press.

Howard, P. N. (2006). New Media Campaigns and the Managed Citizen. New York: Cambridge University Press.

John, N. A. (2013). Sharing and Web 2.0: The Emergence of a Keyword. New Media \& Society, 15, 167-182. doi: 10.1177/1461444812450684

Johnson, T. J., \& Perlmutter, D. D. (2010). Introduction: The Facebook Election. Mass Communication and Society, 13, 554-559. doi:10.1080/15205436.2010.517490

Jungherr, A. (2012). The German Federal Election of 2009: The Challenge of Participatory Cultures in Political Campaigns. Transformative Works and Cultures, 5. doi: 10.3983/twc.2012.0310

Kluver, R., Jankowski, N., Foot., K, \& Schneider, S. (Eds.) (2007). The Internet and National Elections: A Comparative Study of Web Campaigning. London: Routledge. 
Larsson, A. O., \& Moe, H. (2012). Studying Political Microblogging: Twitter Users in the 2010 Swedish Election Campaign. New Media \& Society, 14, 729-747. doi:

$10.1177 / 1461444811422894$

Lilleker, D. G, Koc-Michalska, K., Schweitzer, E. J., Jacunski, M., Jackson, N., \& Vedel, T. (2011). Informing, Engaging, Mobilizing or Interacting: Searching for a European Model of Web Campaigning. European Journal of Communication, 26, 195-213. doi:

$10.1177 / 0267323111416182$

Lilleker, D. G. (2014). Political Communication and Cognition. Basingstoke: Palgrave.

Lilleker, D. G., \& Jackson, N. A. (2010). Towards a More Participatory Style of Election Campaigning: The Impact of Web 2.0 on the UK 2010 General Election. Policy \& Internet, 2, 67-96. doi: 10.2202/1944-2866.1064

Lilleker, D. G., \& Koc-Michalska, K. (2013). Online Political Communication Strategies: MEPs, E-Representation and Self-Representation. Journal of Information Technology \& Politics, 10, 190-207. doi: 10.1080/19331681.2012.758071

Lilleker, D., \& Jackson, N. (2011). Political Campaigning, Elections and the Internet:

Comparing the US, UK, France and Germany. London: Routledge.

Lilleker, D., \& Vedel, T. (2013). The Internet in Campaigns and Elections. In W. Dutton (Ed.), Oxford Handbook of Internet Studies (pp. 401-420). Oxford: Oxford University Press.

Macková, A., Fialová, M., \& Štětka, V. (2013). Nová média jako nástroj politické kampaně v České republice: př́ípadová studie krajských a senátních voleb 2012. Politologický Časopis - Czech Journal of Political Science, 20, 507-525. doi: 10.5817/PC2013-4-507

Mazzoleni, G., \& Schulz, W. (1999). "Mediatization” of politics: A Challenge for Democracy? Political Communication, 16, 247-261. doi: 10.1080/105846099198613 
Negrine, R., \& Papathanassopoulos, S. (1996). The “Americanization” of Political

Communication: A Critique. The Harvard International Journal of Press/Politics, 1, 45-

62. doi: 10.1177/1081180X96001002005

Nielsen, R. K., \& Vaccari, C. (2013). Do People "Like" Politicians on Facebook? Not Really. Large-Scale Direct Candidate-to-Voter Online Communication as an Outlier

Phenomenon. International Journal of Communication, 7, 2333-2356 doi: 1932$8036 / 20130005$

Norris, P. (2000). A Virtuous Circle: Political Communications in Postindustrial Societies. Cambridge: Cambridge University Press.

Norris, P. (2003). Preaching to the Converted? Pluralism, Participation and Party Websites. Party Politics, 9, 21-45. doi: 10.1177/135406880391003

Plasser, F., \& Plasser G. (2003). Global Political Campaigning: A Worldwide Analysis of Campaign Professionals and Their Practices. Westport, CT \& London.

Plasser, F., Scheucher C., \& Senft, C. (1999). Is There a European Style of Political

Marketing? In B. I. Newman (Ed.), Handbook of Political Marketing (pp. 89-112).

Thousand Oaks: Sage.

Strandberg, K. (2013). A Social Media Revolution or Just a Case of History Repeating Itself? The Use of Social Media in the 2011 Finnish Parliamentary Elections. New Media \& Society, 15, 1329-1347. doi:10.1177/1461444812470612

Strömbäck, J. (2009). Selective Professionalisation of Political Campaigning: A Test of the Party-Centered Theory of Professionalised Campaigning in the Context of the 2006 Swedish Election. Political Studies, 57, 95-116. doi: 0.1111/j.1467-9248.2008.00727.x Sudulich, L. M. (2009, April). Do Ethos, Ideology; Country and Electoral Strength Make a Difference in Cyberspace? Testing an Explanatory Model of Parties' Websites. Paper presented at the ECPR Joint Sessions, Lisbon. Retrieved from http://ecpr.eu/Filestore/PaperProposal/09b682fd-f5d5-44f6-b0b7-315379e3ec36.pdf 
Swanson, D. L., \& Mancini, P. (Eds.) (1996). Politics, Media, and Modern Democracy: An International Study of Innovations in Electoral Campaigning and Their Consequences. Westport: Praeger.

Tenscher, J. (2013). First- and Second-Order Campaigning: Evidence from Germany. European Journal of Communication, 28, 241-258. doi: 10.1177/0267323113477633

Tenscher, J., \& Mykkänen, J. (2014). Two Levels of Campaigning. An Empirical Test of the Party-Centred Theory of Professionalisation. Political Studies, 62, 20-41, doi: $10.1111 / 1467-9248.12104$

Tenscher, J., Mykkänen, J., \& Moring, T. (2012). Modes of Professional Campaigning: A Four-Country-Comparison in the European Parliamentary Elections 2009. The International Journal of Press/Politics, 17, 145-168. doi: 10.1177/1940161211433839.

Vaccari, C., Valeriani, A., Barberá, P., Bonneau, R., Jost, J. T., Nagler, J., \& Tucker, J. (2013). Social Media and Political Communication: A Survey of Twitter Users during the 2013 Italian General Election. Rivista Italiana di Scienza Politica, 43, 381-410. doi: $10.1426 / 75245$

Vergeer, M., Hermans, L., \& Cunha C. (2013). Web Campaigning in the 2009 European Parliament Elections: A Cross-National Comparative Analysis. New Media \& Society, 15, 128-148. Doi: 10.1177/1461444812457337

Ward, S., Owen, D., Davis, R., \& Taras, D. (Eds.) (2008). Making a Difference: A Comparative View of the Role of the Internet in Election Politics. Lanham, MD: Lexington Books.

Williams, C. B., \& Gulati, G. J. (2013). Social Networks in Political Campaigns: Facebook and the Congressional Elections of 2006 and 2008. New Media \& Society, 15, 52-71. doi: $10.1177 / 1461444812457332$

Zittel, T. (2004). Political Communication and Electronic Democracy: American Exceptionalism or Global Trend? In F. Esser \& B. Pfetsch (Eds.), Comparing Political 
Communication: Theories, Cases, and Challenges (pp. 231-250). Cambridge \& New York: Cambridge University Press. 
Table 1. Country characteristics (October $31^{\text {st }}$ 2013)

\begin{tabular}{|c|c|c|c|c|c|c|c|c|c|c|c|c|}
\hline & Austria & $\begin{array}{c}\text { Czech } \\
\text { Republic }\end{array}$ & Finland & France & Germany & Hungary & Malta & Netherlands & Portugal & Slovakia & Spain & $\begin{array}{c}\text { United } \\
\text { Kingdom }\end{array}$ \\
\hline Political system & $\begin{array}{l}\text { semi- } \\
\text { presidential } \\
\text { quasi- } \\
\text { parliamentary } \\
\text { democracy }\end{array}$ & $\begin{array}{l}\text { parliamentary } \\
\text { democracy }\end{array}$ & $\begin{array}{l}\text { parliamentary } \\
\text { democracy }\end{array}$ & $\begin{array}{l}\text { semi- } \\
\text { presidential } \\
\text { parliamentary } \\
\text { democracy }\end{array}$ & $\begin{array}{l}\text { parliamentary } \\
\text { democracy }\end{array}$ & $\begin{array}{l}\text { parliamentary } \\
\text { democracy }\end{array}$ & $\begin{array}{l}\text { parliamentary } \\
\text { democracy }\end{array}$ & $\begin{array}{l}\text { parliamentary } \\
\text { monarchy/ } \\
\text { democracy }\end{array}$ & $\begin{array}{l}\text { semi- } \\
\text { presidential } \\
\text { quasi- } \\
\text { parliamentary } \\
\text { democracy }\end{array}$ & $\begin{array}{l}\text { parliamentary } \\
\text { democracy }\end{array}$ & $\begin{array}{l}\text { parliamentary } \\
\text { monarchy/ } \\
\text { democracy }\end{array}$ & $\begin{array}{l}\text { parliamentary } \\
\text { monarchy/ } \\
\text { democracy }\end{array}$ \\
\hline $\begin{array}{l}\text { First democratic } \\
\text { election }\end{array}$ & 1945 & 1990 & 1907 & 1875 & 1949 & 1990 & 1966 & 1945 & 1975 & 1990 & 1977 & 1832 \\
\hline Last national elections & $09 / 2013$ & 10/2013 & 03/2011 & $06 / 2012$ & 09/2013 & 05/2010 & 03/2013 & 09/2012 & 06/2011 & 03/2012 & $11 / 2011$ & 05/2010 \\
\hline Electoral g system & $\begin{array}{l}\text { proportional } \\
\text { party list } \\
\text { voting with } \\
\text { preferential } \\
\text { voting } \\
\text { (electoral } \\
\text { numbers) }\end{array}$ & $\begin{array}{l}\text { proportional } \\
\text { candidate/part } \\
\text { y voting with } \\
\text { preferential } \\
\text { voting }\end{array}$ & $\begin{array}{l}\text { proportional } \\
\text { candidate/part } \\
\text { y voting } 1\end{array}$ & $\begin{array}{l}\text { first past the } \\
\text { post candidate } \\
\text { voting in } \\
\text { single member } \\
\text { legislative } \\
\text { districts, two- } \\
\text { rounds system }\end{array}$ & $\begin{array}{l}\text { proportional } \\
\text { candidate/part } \\
\text { y voting }\end{array}$ & $\begin{array}{l}\text { individual } \\
\text { constituency } \\
\text { seats; } \\
\text { combined } \\
\text { regional and } \\
\text { national party } \\
\text { lists }\end{array}$ & $\begin{array}{l}\text { proportional } \\
\text { candidate } \\
\text { voting with } \\
\text { single } \\
\text { transferable } \\
\text { votes }\end{array}$ & $\begin{array}{l}\text { proportional } \\
\text { party list } \\
\text { voting with } \\
\text { preferential } \\
\text { voting }\end{array}$ & $\begin{array}{l}\text { proportional } \\
\text { party voting, } \\
\text { closed list }\end{array}$ & $\begin{array}{l}\text { proportional } \\
\text { party voting } \\
\text { with } \\
\text { preferential } \\
\text { voting }\end{array}$ & $\begin{array}{l}\text { proportional } \\
\text { candidate/part } \\
\text { y voting }\end{array}$ & $\begin{array}{l}\text { first past the } \\
\text { post candidate } \\
\text { voting in } \\
\text { single } \\
\text { member } \\
\text { legislative } \\
\text { districts }\end{array}$ \\
\hline Type of government & Coalition & Coalition & Coalition & $\begin{array}{l}\text { Coalition/ } \\
\text { Block }\end{array}$ & $\begin{array}{l}\text { Coalition/ } \\
\text { Block }\end{array}$ & Coalition & One party & Coalition & $\begin{array}{l}\text { Majoritarian/cu } \\
\text { rrently a } \\
\text { coalition }\end{array}$ & Coalition & Majoritarian & $\begin{array}{l}\text { Majoritarian/ } \\
\text { currently a } \\
\text { coalition }\end{array}$ \\
\hline $\begin{array}{l}\text { Number of parties in } \\
\text { parliament }\end{array}$ & 6 & 7 & 9 & 9 & 5 & 4 & 2 & 11 & 5 & 7 & $7 / 16^{2}$ & $10^{3}$ \\
\hline $\begin{array}{l}\text { Number od parties } \\
\text { participating in this } \\
\text { study }\end{array}$ & 5 & 5 & 7 & 8 & 6 & 5 & 1 & 8 & 5 & 6 & 6 & 6 \\
\hline Party system & $\begin{array}{l}\text { moderate } \\
\text { pluralistic }\end{array}$ & $\begin{array}{l}\text { polarized } \\
\text { pluralistic }\end{array}$ & $\begin{array}{l}\text { polarized to } \\
\text { moderate } \\
\text { pluralistic }\end{array}$ & $\begin{array}{l}\text { moderate } \\
\text { pluralistic }\end{array}$ & $\begin{array}{l}\text { moderate } \\
\text { pluralistic }\end{array}$ & $\begin{array}{l}\text { polarized to } \\
\text { moderate } \\
\text { pluralistic }\end{array}$ & $\begin{array}{l}\text { polarized } \\
\text { pluralist }\end{array}$ & $\begin{array}{l}\text { moderate } \\
\text { pluralistic }\end{array}$ & $\begin{array}{l}\text { moderate to } \\
\text { polarized } \\
\text { pluralistic }\end{array}$ & $\begin{array}{l}\text { moderate } \\
\text { pluralistic }\end{array}$ & $\begin{array}{l}\text { moderate to } \\
\text { polarized } \\
\text { pluralistic }\end{array}$ & $\begin{array}{l}\text { polarized } \\
\text { pluralistic }\end{array}$ \\
\hline $\begin{array}{l}\text { Model of media and } \\
\text { politics }\end{array}$ & $\begin{array}{l}\text { democratic } \\
\text { corporatist }\end{array}$ & transitory & $\begin{array}{l}\text { democratic } \\
\text { corporatist }\end{array}$ & $\begin{array}{l}\text { polarized } \\
\text { pluralist }\end{array}$ & $\begin{array}{l}\text { democratic } \\
\text { corporatist }\end{array}$ & transitory & $\begin{array}{l}\text { polarized } \\
\text { pluralist }\end{array}$ & $\begin{array}{l}\text { democratic } \\
\text { corporatist }\end{array}$ & $\begin{array}{l}\text { polarized } \\
\text { pluralist }\end{array}$ & transitory & $\begin{array}{l}\text { polarized } \\
\text { pluralist }\end{array}$ & liberal \\
\hline $\begin{array}{l}\text { Limitations to electoral } \\
\text { expenses }\end{array}$ & Yes & No & Yes & Yes & No & Yes & Yes & No & Yes & No & Yes & Yes \\
\hline $\begin{array}{l}\text { Restrictions on } \\
\text { advertising }\end{array}$ & Moderate & Moderate & None & Strict & Moderate & Moderate & Moderate & No & Moderate & Moderate & Moderate & Moderate \\
\hline
\end{tabular}

\footnotetext{
${ }^{1}$ One member (from the Åland Islands) is elected by a simple majority vote.

${ }^{2}$ There are 7 parliamentary groups. One of them is called „Plural Left” (composed of three parties that agreed to distribute territories where they were able to run) and another is called „Mixed Group” with eight parties.

${ }^{3}$ Plus The Speaker and one Independent
} 
Table 2. Evaluation of mediated and direct modes of professional campaigning

\begin{tabular}{lcc}
\hline & Mean & SD \\
\hline Mediated communication & 4.57 & 0.630 \\
Presence of party and top candidates on TV & 3.03 & 1.727 \\
Use of internet advertisements & 2.68 & 1.966 \\
Use of paid media such as TV spots, posters or advertisements & 4.57 & 0.816 \\
Direct communication & 4.00 & 0.914 \\
Communication with voters face to face & 3.87 & 1.413 \\
Communication with voters via Facebook & 3.51 & 1.228 \\
Canvassing & 3.46 & 1.043 \\
Communication with voters via email & 3.32 & 1.190 \\
Communication with voters via YouTube & 3.16 & 1.253 \\
Communication with voters via twitter & 2.69 & 1.273 \\
\hline Communication with voters via other "new" media & & \\
Communication with voters via telephone & & \\
\hline
\end{tabular}

Note: Scale: 1 ("not at all important") to 5 ("very important"), $\mathrm{N}=68$; missing values were set to 0

italicized "traditional" modes of campaigning 
Table 3. Bivariate correlations between direct and new modes of campaigning and macro-level factors (Pearson's r)

\begin{tabular}{|c|c|c|c|c|c|}
\hline & email & Facebook & Twitter & YouTube & Other new media \\
\hline Facebook & $.519 * *$ & & & & \\
\hline Twitter & $.273 *$ & $.439 * *$ & & & \\
\hline YouTube & $.269 *$ & $.470 * *$ & $.529 * *$ & & \\
\hline Other new media & -.152 & .143 & $.375^{* *}$ & $.308 *$ & \\
\hline Number of parties in parliament & -.080 & -.227 & .204 & -.206 & .025 \\
\hline Experience with democratic elections (in years) & -.084 & $-.395 * *$ & -.050 & -.194 & -.001 \\
\hline Size of population & -1.09 & $-.287^{*}$ & .045 & -.084 & $.253^{*}$ \\
\hline GDP & -.088 & $-.313 * *$ & $.249 *$ & -.163 & .084 \\
\hline Literacy rate (PISA 2009) & -.186 & -.149 & -.015 & $-.265^{*}$ & -.133 \\
\hline Internet penetration & -.063 & -.235 & .118 & -.135 & -.080 \\
\hline Political interest & .020 & -.070 & .090 & .053 & .051 \\
\hline Turnout in last national elections & -.102 & -.211 & $.299 *$ & -.046 & -.159 \\
\hline
\end{tabular}

Note: $\mathrm{N}=68 ; * * \mathrm{p}<0.01 ; * \mathrm{p}<0.05$ 
Table 4. Comparisons of means between direct and new modes of campaigning and macro-level factors (in brackets SD)

\begin{tabular}{|c|c|c|c|c|c|}
\hline & Email & Facebook & Twitter & YouTube & Other new media \\
\hline \multicolumn{6}{|l|}{ Country groups } \\
\hline Old EU member states & $3.41(1.152)$ & $3.82(.932)$ & $3.49(1.155)$ & $3.31(1.086)$ & $3.27(1.201)$ \\
\hline New EU member states & $3.82(1.425)$ & $4.53(.624)$ & $2.82(1.185)$ & $3.88(.781)$ & $2.82(1.380)$ \\
\hline F-test & 1.444 (n.s.) & $8.445 * *$ & $4.192 *$ & $3.958^{+}$ & 1.668 (n.s.) \\
\hline \multicolumn{6}{|c|}{ Model of media and politics } \\
\hline Liberal & $4.00(.894)$ & $3.17(1.169)$ & $3.33(1.366)$ & $3.33(1.366)$ & $2.50(1.378)$ \\
\hline Democratic corporatist & $3.42(.987)$ & $3.88(.864)$ & $3.69(.970)$ & $3.35(.745)$ & $3.23(1.032)$ \\
\hline Polarized pluralist & $3.15(1.387)$ & $3.95(.887)$ & $3.20(1.322)$ & $3.30(1.380)$ & $3.40(1.501)$ \\
\hline Transformatory & $3.94(1.389)$ & $4.56(.629)$ & $2.88(1.204)$ & $3.88(.806)$ & $3.00(1.211)$ \\
\hline$F$-test & 1.626 (n.s.) & $4.428 * *$ & 1.715 (n.s.) & 1.141 (n.s.) & .910 (n.s.) \\
\hline \multicolumn{6}{|c|}{ Limitations of campaign expenses } \\
\hline No & $3.64(1.254)$ & $4.16(.850)$ & $3.52(1.122)$ & $3.56(.821)$ & $2.92(1.115)$ \\
\hline Yes & $3.44(1.221)$ & $3.91(.947)$ & $3.21(1.226)$ & $3.40(1.158)$ & $3.30(1.319)$ \\
\hline$F$-test & .408 (n.s.) & 1.215 (n.s.) & 1.079 (n.s.) & .390 (n.s.) & 1.428 (n.s.) \\
\hline \multicolumn{6}{|c|}{ Restrictions on advertising } \\
\hline None & $3.33(.976)$ & $3.87(.743)$ & $3.60(.986)$ & $3.00(.378)$ & $2.67(.900)$ \\
\hline Moderate & 3.67 (1.187) & $4.09(.949)$ & $3.36(1.190)$ & $3.67(.977)$ & $3.20(1.254)$ \\
\hline Strict & $3.00(1.773)$ & $3.75(1.035)$ & $2.63(1.408)$ & $3.13(1.808)$ & $3.88(1.553)$ \\
\hline$F$-test & 1.219 (n.s.) & .665 (n.s.) & 1.845 (n.s.) & $2.912^{+}$ & $2.607^{+}$ \\
\hline
\end{tabular}

Note: Scale: 1 ("not at all important") to 5 ("very important"), $\mathrm{N}=68$; missing values were set to 0 $* * \mathrm{p}<0.01 ; * \mathrm{p}<0.05$ 
Table 5. Cluster analysis on evaluations of direct and new modes of campaigning $(\mathrm{N}=63)$

\begin{tabular}{lcccccc}
\hline & Email & Facebook & Twitter & YouTube & $\begin{array}{c}\text { Other } \\
\text { new media }\end{array}$ & Label \\
\hline Cluster 1 & 4.26 & 4.57 & 4.3 & 4.3 & 4.04 & Generalists \\
Cluster 2 & 2.86 & 3.43 & 2.76 & 3.05 & 2.81 & Average Users \\
Cluster 3 & 4.42 & 4.33 & 3.42 & 3.08 & 1.92 & Selective Users \\
Cluster 4 & 1.14 & 3.43 & 3.14 & 3.14 & 4.57 & Email Avoiders \\
\hline
\end{tabular}

First step: hierarchical cluster analysis (Ward); second step: K-means cluster analysis; 5 outlier cases;

Note: Scale: 1 ("not at all important") to 5 ("very important"), $\mathrm{N}=68$; missing values were set to 0

\begin{tabular}{|c|c|c|c|}
\hline Cluster $1(n=23)$ & Cluster $2(n=21)$ & Cluster $3(n=12)$ & Cluster $4(n=7)$ \\
\hline BZÖ & $\mathrm{BE}$ & $\mathrm{CDA}$ & FN \\
\hline CDS-PP & $\mathrm{CDU}$ & $\mathrm{CU}$ & Grüne \\
\hline $\mathrm{CiU}$ & Con & Együtt 2 & KOK \\
\hline D66 & CSSD & GP & $\mathrm{LO}$ \\
\hline FAC & GL & KDU-CSL & Most-Híd \\
\hline FDP & IU & LD & PG \\
\hline FPÖ & KESK & PRG & UPyD \\
\hline Grüne & LMP & PS & \\
\hline Jobbik & OL-NO & PvdD & \\
\hline KDH & ÖVP & SGP & \\
\hline Lab & PCP & SPOZ & \\
\hline Linke & $\mathrm{PP}$ & TOP 09 & \\
\hline MoDem & PS & & \\
\hline MSZP & PvdA & & \\
\hline ODS & RKP & & \\
\hline PCF & SDKÚ-DS & & \\
\hline Piraten & SDP & & \\
\hline PS & SP & & \\
\hline PSD & SPÖ & & \\
\hline PSOE & VAS & & \\
\hline Sloboda & VIHR & & \\
\hline SNP & & & \\
\hline SPD & & & \\
\hline 23 & & & \\
\hline
\end{tabular}


Table 6. Comparisons of means MW (in brackets SD)

\begin{tabular}{|c|c|c|c|c|c|}
\hline & Email & Facebook & Twitter & YouTube & Other new media \\
\hline \multicolumn{6}{|l|}{ Party type } \\
\hline Catch-all party & $3.75(1.079)$ & $4.03(0.941)$ & $3.39(1.202)$ & $3.50(1.082)$ & $2.92(1.204)$ \\
\hline Client party & $3.25(1.344)$ & $3.97(.897)$ & $3.25(1.191)$ & $3.41(1.012)$ & $3.44(1.268)$ \\
\hline$F$-test & $2.889^{+}$ & .070 (n.s.) & .228 (n.s.) & .135 (n.s.) & $3.014^{+}$ \\
\hline \multicolumn{6}{|c|}{ Parliamentary role } \\
\hline Not in parliament & $3.50(1.378)$ & $3.67(1.751)$ & $2.50(1.225)$ & $2.50(1.378)$ & $2.83(1.602)$ \\
\hline Opposition & $3.58(1.266)$ & $4.08(.818)$ & $3.61(1.175)$ & $3.63(.998)$ & $3.29(1.088)$ \\
\hline Government & $3.42(1.176)$ & $3.96(.806)$ & $3.08(1.100)$ & $3.42(.929)$ & $3.04(1.429)$ \\
\hline$F$-test & .126 (n.s.) & .558 (n.s.) & $3.186^{*}$ & $3.287 *$ & .506 (n.s.) \\
\hline \multicolumn{6}{|l|}{ Party position } \\
\hline Fringe party ${ }^{\dagger}$ & $2.83(1.337)$ & $3.75(1.055)$ & $3.08(1.165)$ & $3.42(1.379)$ & $4.00(1.128)$ \\
\hline Centre party ${ }^{\dagger \dagger}$ & $3.66(1.164)$ & $4.05(.883)$ & $3.38(1.199)$ & $3.46(.972)$ & $2.98(1.213)$ \\
\hline$F$-test & $4.739 *$ & 1.091 (n.s.) & .590 (n.s.) & .020 (n.s.) & $7.114 *$ \\
\hline
\end{tabular}

Note: Scale: 1 ("not at all important") to 5 ("very important"), $\mathrm{N}=68$; missing values were set to 0 ${ }^{+} \mathrm{p}<0.1 * ; \mathrm{p}<0.05 ; * * \mathrm{p}<0.01$

${ }^{\dagger}$ either extreme left-wing (code 1) or right-wing (code 5) party

${ }^{\dagger}$ positioned at the center of the left-right-spectrum (codes $2,3,4$ ) 
Table 7. Explanations of evaluations of new and direct media campaign channels (Beta values)

Email Facebook Twitter YouTube Other new media

\section{Country level}

\begin{tabular}{lcrrrr} 
Old/new EU member state & 1.311 & .896 & .627 & .811 & .752 \\
Fragmentation of the parliamentary system & .018 & -.124 & -.061 & -.292 & -.304 \\
Experience with democratic elections & $-1.087^{*}$ & $-1.008^{+}$ & -.599 & -.093 & -.626 \\
Size of the population & .142 & .065 & .202 & .183 & $.510^{+}$ \\
GDP & $3.730^{* *}$ & 1.915 & .879 & -.135 & .102 \\
Literacy rate & .188 & .504 & .370 & .157 & .354 \\
Interest in politics & $-1.781^{*}$ & -1.029 & -.801 & -.484 & -.331 \\
Turnout in last parliamentary election & -1.621 & -.583 & .546 & 1.227 & .978 \\
Campaign regulations: limitations of expenses & -.283 & -.050 & -.043 & .131 & $.603 *$ \\
Campaign regulations: restricted advertising & -.723 & -.087 & .204 & .565 & .766 \\
Party level & & & & & .039 \\
Party's age & $-.410^{* *}$ & $-.358^{*}$ & -.175 & $-.372 *$ & .039 \\
Ideology & .079 & .219 & .230 & .099 & .049 \\
Party type (catch-all) & $.363^{+}$ & .076 & .138 & -.124 & -.252 \\
Parliamentary role (governing) & -1.27 & -.154 & -.039 & .065 & .013 \\
Parliamentary size & .097 & .076 & -.201 & .059 & .129 \\
External shock & -1.81 & -.205 & -.105 & -.198 & -.171 \\
Internal shock & $.316^{+}$ & .110 & .036 & .021 & .137 \\
Constant & 13.465 & -3.850 & -11.432 & -8.635 & -19.599 \\
\hline $\mathrm{R}^{2}$ & .399 & .362 & .361 & .237 & .413 \\
Adjusted $R^{2}$ & .155 & .103 & .103 & -.071 & .175 \\
\hline
\end{tabular}

Note: OLS Linear Regressions, $\mathrm{N}=68,{ }^{+} \mathrm{p}<0.1 ; * \mathrm{p}<0.05 ; * * \mathrm{p}<0.01$

Model of media and politics and internet penetration not included due to high colinearity 
Figure 1. Countries' evaluations of mediated and traditional versus direct and new campaign channels

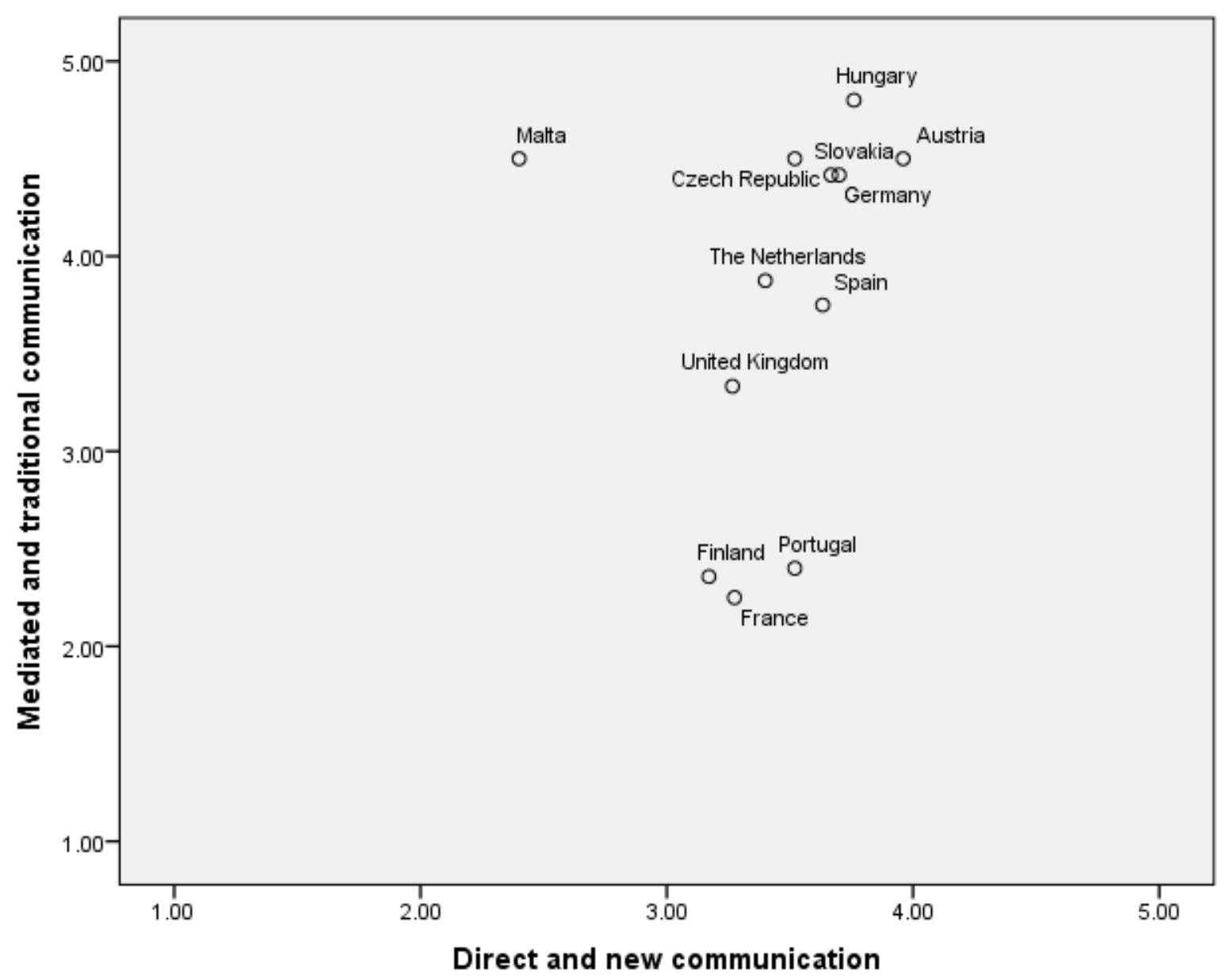

Note: Scale: 1 ("not at all important") to 5 ("very important"), $\mathrm{N}=68$; missing values were set to 0 Pearson's $r=.219$ (n.s.) 
Figure 2. Parties' evaluations of mediated and traditional versus direct and new campaign channels

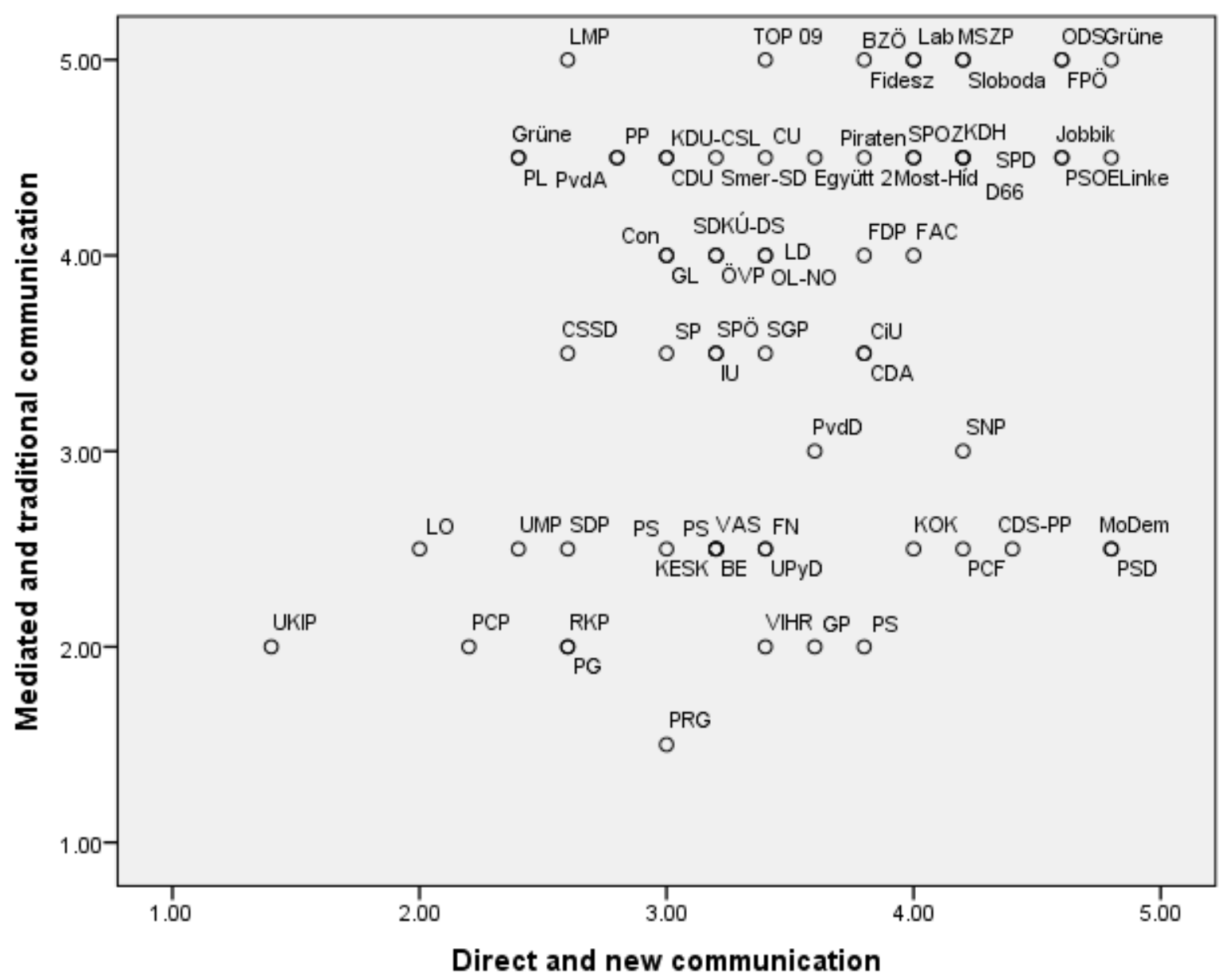

Note: Scale: 1 ("not at all important") to 5 ("very important"), $\mathrm{N}=68$; missing values were set to 0 Pearson's $\mathrm{r}=.336(\mathrm{p}<0.01)$ 